\title{
Humanização em Terapia Intensiva - Aspectos Iniciais
}

\author{
Ferreira Junior, Firmino Haag; Rodrigues Junior, Wilson; Aguiar, Thais Nogueira; \\ Giusti, Rosilene; Buffon, Marcela \\ Hospital Cruz Azul de São Paulo — afhaag@uol.com.br
}

Objetivo: Avaliar a implantação de um processo de humanização com foco no alojamento compartilhado. Método: Análise temporal, prospectivo do Mês de fevereiro a junho de 2010, relacionado ao processo de Alojamento compartilhado. Avaliar a satisfação do paciente/familiar no processo de alojamento compartilhado através de questionários. Resultados: no Mês de fevereiro a Junho 2010 ? pacientes participaram do processo do Alojamento compartilhado sendo que não houve nenhuma resposta insatisfatória, 100\% responderam que o alojamento proporcionou segurança e confiança. Não houve impacto na taxa de infecção e ,mortalidade da Unidade. Discussão: o foco dos processos de Humanização em saúde, visa respeitar a individualidade dos pacientes, incorporando e respeitando os seus valores, expectativas, aspectos culturais, preocupações, garantindo qualidade da comunicação entre família, paciente e equipe com o objetivo na melhoria da assistência. Conclusão: Através dos dados obtidos, considerando que a Humanização favorece uma melhor interação psicossocial em pacientes internados em terapia intensiva.

Ferreira Junior, Firmino Haag; Rodrigues Junior, Wilson; Aguiar, Thais Nogueira; Giusti, Rosilene; Buffon, Marcela. Humanização em Terapia Intensiva - Aspectos Iniciais. In: Anais do Congresso Internacional de Humanidades \& Humanização em Saúde [= Blucher Medical Proceedings, num.2, vol.1]. São Paulo: Editora Blucher, 2014. ISSN 2357-7282 DOI 10.5151/medpro-cihhs-10346 